\title{
Transgenic Models in Retinoblastoma Research
}

\author{
Rohini M. Nair Geeta K. Vemuganti \\ School of Medical Sciences, University of Hyderabad, Hyderabad, India
}

\section{Key Words}

Retinoblastoma · Transgenic models · Tumorigenesis $\cdot$ LH $\beta$-Tag $\cdot$ Knockout models

\begin{abstract}
Understanding the mechanism of retinoblastoma $(\mathrm{Rb})$ tumor initiation, development, progression and metastasis in vivo mandates the use of animal models that mimic this intraocular tumor in its genetic, anatomic, histologic and ultrastructural features. An early setback for developing mouse $\mathrm{Rb}$ models was that $\mathrm{Rb}$ mutations did not cause tumorigenesis in murine retinas. Subsequently, the discovery that the p107 protein takes over the role of pRb in mice led to the development of several animal models that phenotypically and histologically resemble the human form. This paper summarizes the transgenic models that have been developed over the last three decades.

(c) 2015 S. Karger AG, Basel
\end{abstract}

\section{LH $\beta$-Tag Mouse Model}

Windle et al. [1] developed the first retinoblastoma ( $\mathrm{Rb}$ ) transgenic mouse model in 1990 using the simian virus 40 (SV40) large T antigen (Tag) gene cohybridized with the luteinizing hormone $\beta$-subunit (LH $\beta$ ) gene as promoter. This ensured a low expression of the Tag gene specifically in the gonadotropic cells of the anterior pituitary in many murine lines, one of which developed heritable bilateral ocular neoplasms at about 5 months [1]. The SV40 genome has several oncogenes in both the large $\mathrm{T}$ and the small $\mathrm{t}$ region which are predicted to cause a neoplastic transformation of the tissues by binding to p53, the pRB family and phosphatase pp2A proteins [2]. The murine eye tumors showed the histological characteristics of human $\mathrm{Rb}$, including the presence of the neuronal marker NSE and synaptophysin 
and the absence of S-100 and vimentin [3]. The tumors also showed an endophytic and exophytic growth with invasion of the retina, choroid, optic nerve and vitreous seeding. This model was followed by the development of interphotoreceptor retinoid-binding protein promoter-based Tag $\mathrm{Rb}$ transgenic mice which developed tumors that also showed the neuronal characteristics of human $\mathrm{Rb}[4,5]$. The ocular tumors in these mice exhibited both Flexner-Wintersteiner and Homer-Wright rosettes, which can be observed using light and electron microscopy when the mice are 5 months of age. However, the question regarding the nature of the cell of origin still remains unanswered and debated with histologic evidence pointing towards the amacrine cell layer [6].

The early stages of tumor development in the Tag model were investigated by Pajovic et al. [7] by tracking Tag protein expression in the retina. The SV40 Tag causes neoplastic transformation of the developing retinal cells. Their studies revealed that Tag expression starts within the nuclei of the inner nuclear layer by postnatal day 8 (P8), increases by P21 and then shows a steady decline until the P28 stage. A decreased expression was observed along with an increased expression of activated caspase-3, which indicates apoptosis. The authors also reported expression of Müller glial markers in these Tag-positive cells, which led to the conclusion that the cell of origin in these tumors might be a subset of progenitor-like Müller glial cells that undergoes transformation upon Tag expression.

To further characterize the tumor-initiating cells of the Tag model, Wadhwa et al. [8] established a murine Rb cell line using tumors from P7 mice of the Pax6 Tag model. They identified the presence of a subset of tumor-initiating cells that express known stem cell markers such as CD133, Nestin and Sox2. These CD133 ${ }^{+}$cells were able to generate neurospheres in vitro and to form transplantable tumors in vivo which were identical to the parent tumor. The transgenic $\mathrm{Rb}$ Tag model has been widely used over the past two decades for studying $\mathrm{Rb}$ tumorigenesis and also for evaluating therapeutics such as local chemotherapy, radiation therapy, vascular targeting therapies and cryotherapy [9-13].

Conventional therapies such as local carboplatin chemotherapy and external beam radiotherapy along with angiogenesis inhibitors like anecortave acetate caused increased apoptotic cell death in the Tag Rb model [9]. Intraocular tumor growth was observed to be inhibited by subconjunctival delivery of carboplatin in 5-week-old transgenic BLH SV40 Tagpositive mice with Rb by Murray et al. [10]. Cryotherapy successfully limited tumor growth in these transgenic mice. Combination therapy using intravitreal carboplatin and external beam radiotherapy resulted in better tumor growth control [11]. The use of optical coherence tomography to assess tumor growth in vivo and quantify its development from the early tumor initiation to the advanced stage was also carried out successfully in this model $[14,15]$.

The Rb Tag transgenic model has been an invaluable tool for understanding the origin and tumorigenesis of $\mathrm{Rb}$ and also for assessing various therapeutic interventions at a preclinical stage. However, the use of viral oncogenes to induce tumorigenesis has its setbacks as the interactions of the oncoproteins with other tissue proteins are not fully understood. Also, the Tag model does not exhibit the focal and clonal tumors which are characteristic of human Rb. These two striking disadvantages warrant the need for developing a conditional knockout (KO) model that mimics both the origin and development of human $\mathrm{Rb}$.

\section{Rb KO Animal Models}

The early nineties witnessed the development of gene knockout technology that led to the development of several disease models and other transgenic models that lacked spatial expression of specific genes. Based on this, several researchers attempted to generate $\mathrm{Rb}$ 
chimeric mouse models by conditional knockout of the $\mathrm{Rb}$ gene in the retinas. However, these animals did not develop ocular tumors even though the $\mathrm{Rb}-/-$ cells contributed to the developing central nervous system $[16,17]$. An interesting observation was the presence of ectopic mitoses and massive cellular degeneration in the developing retina of these chimeric embryos. Robanus-Maandag et al. [18] identified p107 as the factor preventing Rb in Rb double KO (DKO) mice. The Rb-related gene p107 was found to be required to facilitate the oncogenic program following $\mathrm{Rb}$ inactivation and to function as a tumor suppressor. The protein p107 is highly similar to pRB1 with respect to its sequence and biologic function [19]. MacPherson et al. [20] and Donovan et al. [21] showed that postnatal murine retinas lack $\mathrm{Rb}$ and that their explant cultures showed a marked upregulation of the p107 gene, unlike human retinas. This confirmed the hypothesis that 107 plays a role similar to that of pRB and compensates for the protein in its absence. The embryos which were double knockouts for Rb and p107 exhibited high developmental lethality. In order to generate living and breedable $\mathrm{Rb}$ mice, selective knockout of these genes in the developing retina was attempted using Cre-lox technology [22]. However, it was observed that the loss of Rb, p107 or p53 in photoreceptors did not result in any malignant transformation. Further attempts were carried out using nestin, Chx10 and Pax6 promoters to create Rb KO models by conditional gene deletion in retinal progenitor and other cells [20, 23-25]. The models thus generated took about 3-9 months to develop detectable tumor masses with tumor cells expressing progenitor, amacrine and Müller glial markers. Nestin-Cre and Pax6-Cre could not be used for further preclinical studies due to their late onset of tumor growth, low penetrance and nonautonomous cellular effects. It was observed that all the viable nestin-Cre KO mice $(n=5 / 11)$ developed tumors in the eye with 4 having bilateral tumors histologically similar to the human form with signs of invasion into the surrounding muscle. The authors reported that the tumors were mostly found filling the area behind the lens and in the inner nuclear layer. Homer-Wright rosettes were observed, and the tumor foci exhibited high levels of mitoses and apoptosis [20]. Phenotypic features that were shared between the Rb deletion models and Cre transgenic lines were the high numbers of mitotic figures, increased cell death in the inner retinal layer from day E16.5-18.5 onwards [17] and photoreceptor degeneration $[18,20]$, with the most conspicuous effect being the extension of the retinogenesis period $[20,24,25]$ and the ectopic proliferation in the retinal ganglion cell layer [26]. The addition of another mutation of p107 in these animal models led to an increase of many developmental phenotypes associated with retinal $\mathrm{Rb}$ loss, which also threw light on the functional synergy between these family members [18, 20, 24]. Apoptotic cell death was observed in specific cell layers following Rb deletion, and in $\alpha$-Cre Rblox/lox mice, the rod, bipolar and ganglion cells were completely degenerated [24]. In the Chx10Cre Rblox/lox model, the bipolar cells did not undergo apoptosis. These experiments showed diverse phenotypic and biological differences between the various models, which could be due to the genetic heterogeneity of the mouse strains and differences in the temporal and spatial expression of the Cre gene across the cell types [27]. These models have rendered an insight into the possible pathway of $\mathrm{Rb}$ tumor initiation following $\mathrm{pRB}$ loss and progression, which makes them suited for testing novel pathway-directed therapies.

$\mathrm{The} \mathrm{Rb} / \mathrm{p} 107$ DKO models demonstrated high levels of retinal proliferation as well as apoptosis, although many of the horizontal, amacrine and Müller cells survived the $\mathrm{Rb}$ and p107 mutation [18, 25, 28, 29]. Many of the DKO animals subsequently developed Rb, and it was interesting to note that, since the tumors arose from highly apoptosis-sensitive cells, the cell of origin seems to bear an inherent resistance to cell death cues. Human $\mathrm{Rb}$ are also known to exhibit areas with increased apoptosis. The delayed tumorigenesis and incomplete penetrance observed in this model led to the development of the Rb/p130 DKO model. Rb-like protein 2 , commonly known as $\mathrm{p} 130$, is known to play an important role in retinal devel- 


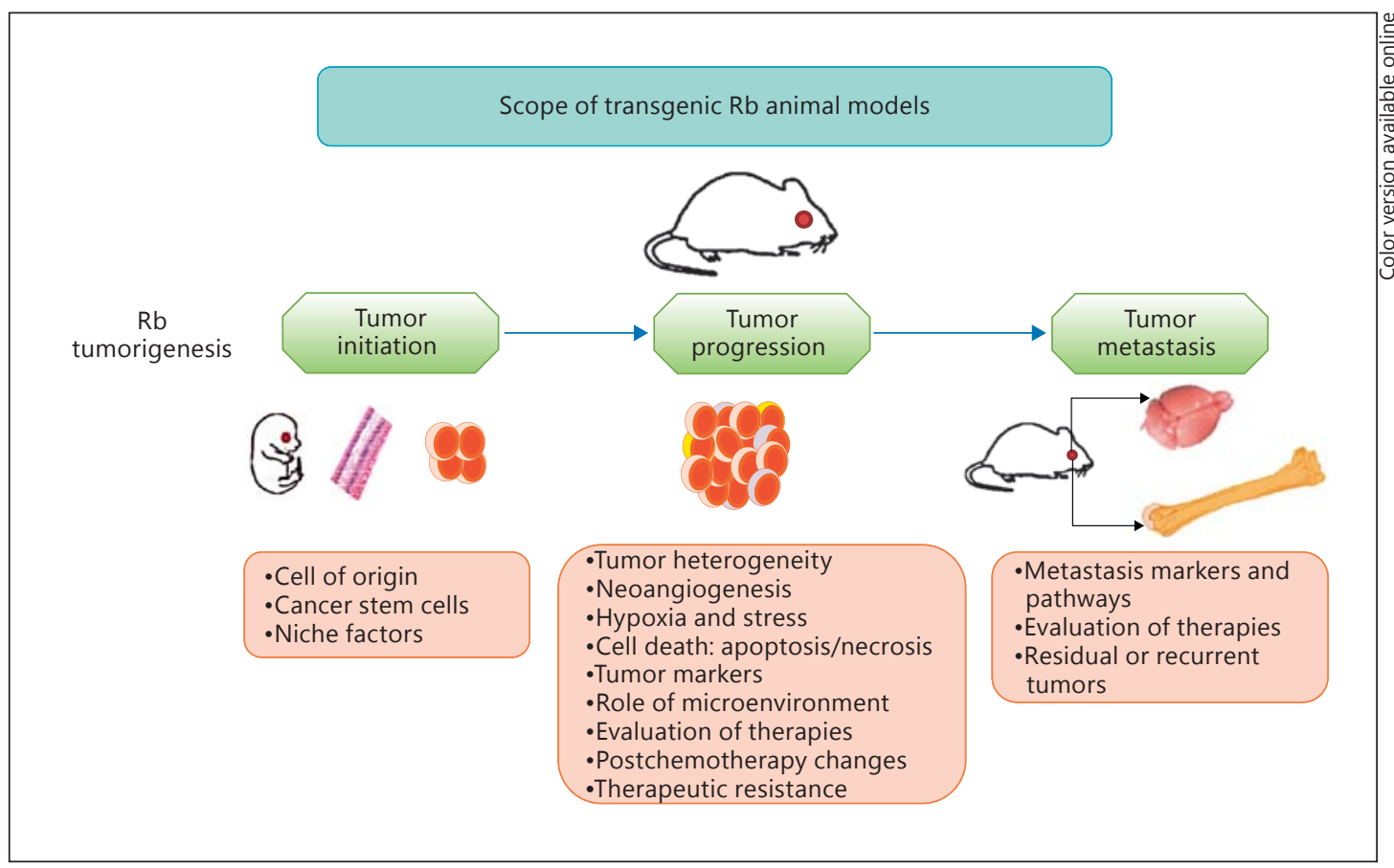

Fig. 1. Transgenic animal models in $\mathrm{Rb}$.

Table 1. Studies using transgenic mouse models to study $\mathrm{Rb}$ tumorigenesis, invasion and therapeutic evaluation

\begin{tabular}{llll}
\hline Rb transgenic model & $\begin{array}{l}\text { Tumor initiation } \\
\text { and progression }\end{array}$ & Metastasis & $\begin{array}{l}\text { Assessment of } \\
\text { therapies }\end{array}$ \\
\hline Tag model & {$[1,3,8]$} & {$[1,3,6]$} & {$[9-13,37-47]$} \\
Rb-/-p107-/- & {$[18,20,25]$} & {$[25]$} & - \\
Rb-/- p130-/- & {$[20,30]$} & {$[20]$} & - \\
$\alpha$-Cre Rblox/lox p130-/- & {$[25,31]$} & {$[25]$} & - \\
NesCre1 Rblox/lox p130-/- & {$[20,25]$} & {$[20,25]$} & - \\
Chx10-Cre;RbLox/Lox;p107-/- & {$[23,24]$} & - & - \\
Chx10-Cre;RbLox/Lox;p130-/-;p107+/- & {$[23,31]$} & {$[31]$} & - \\
Chx10-Cre;RbLox/Lox;p107-/-;p53Lox/Lox & {$[23,29]$} & {$[23,29,35]$} & {$[35,36]$} \\
\hline
\end{tabular}

opment, cell cycle regulation and tumor suppression. NesCre1 Rblox/lox p130-/-, $\alpha$-Cre Rblox/lox p130-/- and Rb-/-p130-/- chimeras substantiated the evidence towards the role of 130 in Rb development [20, 25, 30]. However, the histological deformities in the embryonic retinal development as seen in the NesCre1 Rb/p107 DKO retinas were absent in these models [20]. All of the chimeric mice that lack both Rb and p130 (NesCre1 Rblox/lox p130-/and $\alpha$-Cre Rblox/lox p130-/-) form Rb with a wide array of expressed markers, which include those identifying amacrine and horizontal cell genes [20,25, 30]. Of these models, the $\alpha$-Cre Rblox/lox p130-/- chimeras are more suitable for studying advanced Rb owing to their rapid tumor progression and metastasis. They present with lesions consistent with Homer-Wright rosettes at the retinal periphery as early as P21-31 [25]. The tumor cells proliferate to fill the 
posterior chamber and were observed to invade the optic nerve and extend to the brain. Both DKO models, $\mathrm{Rb} / \mathrm{p} 130$ and $\mathrm{Rb} / 107$, have features that bear resemblance to human $\mathrm{Rb}$ with neuroblastic differentiation and have similar histologic features. Ajioka et al. [31] have generated transgenic mice that express a single copy of Rb1, p107 and p130 in the developing retina. This study helped reveal the role of the $3 \mathrm{Rb}$ family members in $\mathrm{Rb}$ formation. In the heterozygous p107 mutant retina, it was observed that the horizontal neurons start to differentiate normally, but after several weeks, they resume the cell cycle, expand clonally and produce bilateral $\mathrm{Rb}$ that invade into the bone marrow. It is interesting to note that the horizontal cells of the other KO mice [Rb(+/-);p107(-/-);p130(-/-) or Rb(-/-);p107(-/-); $\mathrm{p} 130(+/-)]$ were not affected, which indicates that a single copy of Rb or p130 is enough to control the horizontal cell expansion. The study showed for the first time that neurons were capable of re-entering the cell cycle after differentiation and can form invasive tumors, hinting that $\mathrm{Rb}$ originates from dedifferentiation of horizontal cells [31]. McEvoy et al. [32] conducted an extensive study using the Chx10-Cre system on six mouse lines and generated the KO mice that were histologically similar to each other and to human $\mathrm{Rb}$. The markers expressed in these tumors point to amacrine cell differentiation. The rate of tumor progression and penetrance varied significantly in these strains, which led to their subsequent study on the geneticepigenetic changes that occur during tumorigenesis [33]. A study by Laurie et al. [34] showed that several foci of clonal retinal tumors were formed in newborn p53-deficient mice that had a replication-incompetent retrovirus encoding the E1A 13S oncogene. The model was used to test the efficacy of topotecan in combination with carboplatin and vincristine for $\mathrm{Rb}$ treatment. This model did not exhibit any signs of metastasis during the experimental period, but after 8 months it showed some invasion into the optic nerve and anterior chamber, thereby limiting its use as a metastatic Rb model.

\section{Transgenic Models in Preclinical Testing}

The transgenic $\mathrm{Rb}$ models are well suited for preclinical testing owing to their known genetic lesion and spontaneous tumor development in the eye with well-established vascularization. The genetic KO models serve best for this purpose, as they do not only create lesions that are identical to human $\mathrm{Rb}$ but also share its initial mutations that lead to tumorigenesis.

These models validate the assumption that an in vivo tumor model that comprises the genetic signature of the human malignancy is capable of replicating clinical behavior. Assessing combination therapies in vivo has been a challenge for clinical trials, which is being significantly addressed by these animal models $[10,11,34-36]$. One of the few promising preclinical studies used systemic topotecan and subconjunctival carboplatin for Rb treatment, which not only was shown to ablate the tumor in the KO mice (Chx10-Cre;RbLox/Lox;p107-/-;p53Lox/ Lox) but even restored vision in some of the long-term survivors [35]. The LH $\beta$-Tag and p53 triple-knockout (TKO) models are currently the most preferred transgenic Rb models for preclinical testing of existing and novel therapeutic regimens (table 1).

In conclusion, several genetic models of $\mathrm{Rb}$ have been established that have helped to understand $\mathrm{Rb}$ tumorigenesis and metastasis. These models are more reliable when compared to the orthotopic models for studying the biokinetics of tumor formation, the role of the tumor microenvironment and invasion as well as for assessing several therapeutic strategies for the treatment of $\mathrm{Rb}$ (fig. 1). Genetic animal models form the bridge between translating the basic knowledge about the pathogenesis of $\mathrm{Rb}$ and the development of successful therapies. 


\section{References}

1 Windle JJ, Albert DM, O’Brien JM, Marcus DM, Disteche CM, Bernards R, Mellon PL: Retinoblastoma in transgenic mice. Nature 1990;343:665-669.

-2 Hahn WC, Dessain SK, Brooks MW, King JE, Elenbaas B, Sabatini DM, DeCaprio JA, Weinberg RA: Enumeration of the simian virus 40 early region elements necessary for human cell transformation. Mol Cell Biol 2002;22: 2111-2123.

-3 Kivela T, Virtanen I, Marcus DM, O’Brien JM, Carpenter JL, Brauner E, Tarkkanen A, Albert DM: Neuronal and glial properties of a murine transgenic retinoblastoma model. Am J Pathol 1991;138:1135-1148.

-4 Marcus DM, Lasudry JG, Carpenter JL, Windle J, Howes KA, al-Ubaidi MR, Baehr W, Overbeek PA, Font RL, Albert DM: Trilateral tumors in four different lines of transgenic mice expressing SV40 T-antigen. Invest Ophthalmol Vis Sci 1996;37:392-396.

5 al-Ubaidi MR, Font RL, Quiambao AB, Keener MJ, Liou GI, Overbeek PA, Baehr W: Bilateral retinal and brain tumors in transgenic mice expressing simian virus 40 large $\mathrm{T}$ antigen under control of the human interphotoreceptor retinoid-binding protein promoter. J Cell Biol 1992;119:1681-1687.

6 Albert DM, Griep AE, Lambert PF, Howes KA, Windle JJ, Lasudry JG: Transgenic models of retinoblastoma: what they tell us about its cause and treatment. Trans Am Ophthalmol Soc 1994;92:385-400, discussion 400-401.

7 Pajovic S, Corson TW, Spencer C, Dimaras H, Orlic-Milacic M, Marchong MN, To KH, Theriault B, Auspitz M, Gallie BL: The TAg-RB murine retinoblastoma cell of origin has immunohistochemical features of differentiated Muller glia with progenitor properties. Invest Ophthalmol Vis Sci 2011;52:7618-7624.

-8 Wadhwa L, Bond WS, Perlaky L, Overbeek PA, Hurwitz MY, Chevez-Barrios P, Hurwitz RL: Embryonic retinal tumors in SV40 T-Ag transgenic mice contain CD133+ tumor-initiating cells. Invest Ophthalmol Vis Sci 2012; 53:3454-3462.

-9 Jockovich ME, Suarez F, Alegret A, Pina Y, Hayden B, Cebulla C, Feuer W, Murray TG: Mechanism of retinoblastoma tumor cell death after focal chemotherapy, radiation, and vascular targeting therapy in a mouse model. Invest Ophthalmol Vis Sci 2007;48:5371-5376.

10 Murray TG, Cicciarelli N, O’Brien JM, Hernandez E, Mueller RL, Smith BJ, Feuer W: Subconjunctival carboplatin therapy and cryotherapy in the treatment of transgenic murine retinoblastoma. Arch Ophthalmol 1997;115: 1286-1290.

$>11$ Murray TG, Roth DB, O’Brien JM, Feuer W, Cicciarelli N, Markoe AM, Hernandez E, Smith BJ, Windle JJ: Local carboplatin and radiation therapy in the treatment of murine transgenic retinoblastoma. Arch Ophthalmol 1996;114:1385-1389.

12 Suarez F, Jockovich ME, Hernandez E, Feuer W, Parel JM, Murray TG: Paclitaxel in the treatment of retinal tumors of LH beta-Tag murine transgenic model of retinoblastoma. Invest Ophthalmol Vis Sci 2007;48:34373440.

13 Shah NV, Pham DG, Murray TG, Decatur C, Hernandez E, Shah NN, Cavalcante M, Houston SK: Intravitreal and subconjunctival melphalan for retinoblastoma in transgenic mice. J Ophthalmol 2014;2014:829879.

14 Ruggeri M, Wehbe H, Jiao S, Gregori G, Jockovich ME, Hackam A, Duan Y, Puliafito CA: In vivo three-dimensional high-resolution imaging of rodent retina with spectral-domain optical coherence tomography. Invest Ophthalmol Vis Sci 2007;48:1808-1814.

-15 Dimaras H, Marchong MN, Gallie BL: Quantitative analysis of tumor size in a murine model of retinoblastoma. Ophthalmic Genet 2009;30:84-90.

16 Williams BO, Schmitt EM, Remington L, Bronson RT, Albert DM, Weinberg RA, Jacks T: Extensive contribution of Rb-deficient cells to adult chimeric mice with limited histopathological consequences. EMBO J 1994;13: 4251-4259.

17 Maandag EC, van der Valk M, Vlaar M, Feltkamp C, O’Brien J, van Roon M, van der Lugt N, Berns A, te Riele H: Developmental rescue of an embryonic-lethal mutation in the retinoblastoma gene in chimeric mice. EMBO J 1994;13:4260-4268.

18 Robanus-Maandag E, Dekker M, van der Valk M, Carrozza ML, Jeanny JC, Dannenberg JH, Berns A, te Riele H: p107 is a suppressor of retinoblastoma development in pRb-deficient mice. Genes Dev 1998;12:1599-1609.

19 Zhu L, van den Heuvel S, Helin K, Fattaey A, Ewen M, Livingston D, Dyson N, Harlow E: Inhibition of cell proliferation by 107 , a relative of the retinoblastoma protein. Genes Dev 1993;7:1111-1125.

20 MacPherson D, Sage J, Kim T, Ho D, McLaughlin ME, Jacks T: Cell type-specific effects of Rb deletion in the murine retina. Genes Dev 2004;18:1681-1694.

-21 Donovan SL, Schweers B, Martins R, Johnson D, Dyer MA: Compensation by tumor suppressor genes during retinal development in mice and humans. BMC Biol 2006;4:14.

22 Vooijs M, te Riele H, van der Valk M, Berns A: Tumor formation in mice with somatic inactivation of the retinoblastoma gene in interphotoreceptor retinol binding protein-expressing cells. Oncogene 2002;21:46354645.

23 Zhang J, Schweers B, Dyer MA: The first knockout mouse model of retinoblastoma. Cell Cycle 2004;3:952-959.

-24 Chen D, Livne-bar I, Vanderluit JL, Slack RS, Agochiya M, Bremner R: Cell-specific effects of RB or RB/p107 loss on retinal development implicate an intrinsically death-resistant cell-of-origin in retinoblastoma. Cancer Cell 2004;5:539-551.

25 MacPherson D, Conkrite K, Tam M, Mukai S, Mu D, Jacks T: Murine bilateral retinoblastoma exhibiting rapidonset, metastatic progression and N-myc gene amplification. EMBO J 2007;26:784-794. 
Ocular Oncology

and Pathology
Ocul Oncol Pathol 2015;1:207-213

DOI: $10.1159 / 000370157$

Nair and Vemuganti: Transgenic Models in Retinoblastoma Research

. E2F2, and E2F3 in mediating phenotypes induced by loss of Rb. Cell Growth Differ 2002;13:215-225.

27 Macpherson D: Insights from mouse models into human retinoblastoma. Cell Div 2008;3:9.

28 Masland RH: The fundamental plan of the retina. Nat Neurosci 2001;4:877-886.

-29 Johnson DA, Zhang J, Frase S, Wilson M, Rodriguez-Galindo C, Dyer MA: Neuronal differentiation and synaptogenesis in retinoblastoma. Cancer Res 2007;67:2701-2711.

-30 Dannenberg JH, Schuijff L, Dekker M, van der Valk M, te Riele H: Tissue-specific tumor suppressor activity of retinoblastoma gene homologs p107 and p130. Genes Dev 2004;18:2952-2962.

- 31 Ajioka I, Martins RA, Bayazitov IT, Donovan S, Johnson DA, Frase S, Cicero SA, Boyd K, Zakharenko SS, Dyer MA: Differentiated horizontal interneurons clonally expand to form metastatic retinoblastoma in mice. Cell 2007;131:378-390.

-32 McEvoy J, Flores-Otero J, Zhang J, Nemeth K, Brennan R, Bradley C, Krafcik F, Rodriguez-Galindo C, Wilson M, Xiong S, Lozano G, Sage J, Fu L, Louhibi L, Trimarchi J, Pani A, Smeyne R, Johnson D, Dyer MA: Coexpression of normally incompatible developmental pathways in retinoblastoma genesis. Cancer Cell 2011;20:260-275.

-33 Benavente CA, McEvoy JD, Finkelstein D, Wei L, Kang G, Wang YD, Neale G, Ragsdale S, Valentine V, Bahrami A, Temirov J, Pounds S, Zhang J, Dyer MA: Cross-species genomic and epigenomic landscape of retinoblastoma. Oncotarget 2013;4:844-859.

-34 Laurie NA, Gray JK, Zhang J, Leggas M, Relling M, Egorin M, Stewart C, Dyer MA: Topotecan combination chemotherapy in two new rodent models of retinoblastoma. Clin Cancer Res 2005;11:7569-7578.

-35 Nemeth KM, Federico S, Carcaboso AM, Shen Y, Schaiquevich P, Zhang J, Egorin M, Stewart C, Dyer MA: Subconjunctival carboplatin and systemic topotecan treatment in preclinical models of retinoblastoma. Cancer 2011; 117:421-434.

- 36 Brennan RC, Federico S, Bradley C, Zhang J, Flores-Otero J, Wilson M, Stewart C, Zhu F, Guy K, Dyer MA: Targeting the p53 pathway in retinoblastoma with subconjunctival Nutlin-3a. Cancer Res 2011;71:42054213.

-37 Albert DM, Marcus DM, Gallo JP, O'Brien JM: The antineoplastic effect of vitamin D in transgenic mice with retinoblastoma. Invest Ophthalmol Vis Sci 1992;33:2354-2364.

-38 Murray TG, O’Brien JM, Steeves RA, Smith BJ, Albert DM, Cicciarelli N, Markoe AM, Tompkins DT, Windle JJ: Radiation therapy and ferromagnetic hyperthermia in the treatment of murine transgenic retinoblastoma. Arch Ophthalmol 1996;114:1376-1381.

-39 Dawson DG, Gleiser J, Zimbric ML, Darjatmoko SR, Frisbie JC, Lokken JM, Lindstrom MJ, Audo I, Strugnell SA, Albert DM: Toxicity and dose-response studies of 1 alpha-hydroxyvitamin D2 in LH beta-Tag transgenic mice. Trans Am Ophthalmol Soc 2002;100:125-129.

-40 Hayden BC, Murray TG, Cicciarelli N, Scott IU, Alexandridou A, Hernandez E, Wu X, Markoe AM, Feuer W, Fulton L, O'Brien JM: Hyperfractionated external beam radiation therapy in the treatment of murine transgenic retinoblastoma. Arch Ophthalmol 2002;120:353-359.

41 Dawson DG, Gleiser J, Zimbric ML, Darjatmoko SR, Lindstrom MJ, Strugnell SA, Albert DM: Toxicity and doseresponse studies of 1-alpha hydroxyvitamin D2 in LH-beta-tag transgenic mice. Ophthalmology 2003;110: 835-839.

-42 Tong CT, Howard SA, Shah HR, Van Quill KR, Lin ET, Grossniklaus HE, O'Brien JM: Effects of celecoxib in human retinoblastoma cell lines and in a transgenic murine model of retinoblastoma. Br J Ophthalmol 2005;89:12171220.

-43 Van Quill KR, Dioguardi PK, Tong CT, Gilbert JA, Aaberg TM Jr, Grossniklaus HE, Edelhauser HF, O'Brien JM: Subconjunctival carboplatin in fibrin sealant in the treatment of transgenic murine retinoblastoma. Ophthalmology 2005;112:1151-1158.

44 Jockovich ME, Bajenaru ML, Pina Y, Suarez F, Feuer W, Fini ME, Murray TG: Retinoblastoma tumor vessel maturation impacts efficacy of vessel targeting in the LH(BETA)T(AG) mouse model. Invest Ophthalmol Vis Sci 2007;48:2476-2482.

45 Pina Y, Decatur C, Murray TG, Houston SK, Lopez-Cavalcante M, Hernandez E, Celdran M, Shah N, Feuer W, Lampidis T: Retinoblastoma treatment: utilization of the glycolytic inhibitor, 2-deoxy-2-fluoro-D-glucose (2-FG), to target the chemoresistant hypoxic regions in LH(BETA)T(AG) retinal tumors. Invest Ophthalmol Vis Sci 2012;53:996-1002.

46 Kang SJ, Durairaj C, Kompella UB, O'Brien JM, Grossniklaus HE: Subconjunctival nanoparticle carboplatin in the treatment of murine retinoblastoma. Arch Ophthalmol 2009;127:1043-1047.

47 Boutrid H, Pina Y, Cebulla CM, Feuer WJ, Lampidis TJ, Jockovich ME, Murray TG: Increased hypoxia following vessel targeting in a murine model of retinoblastoma. Invest Ophthalmol Vis Sci 2009;50:5537-5543. 